\title{
Trends of Income Inequality and Poverty Involvement: Panel Evidence from Bali Province
}

\author{
Muhammad Amrullah ${ }^{1, *}$ M. Pudjihardjo ${ }^{2,}$ Iswan Noor $^{3}$, Setyo Tri Wahyudi ${ }^{4}$ \\ ${ }^{1,2,3,4}$ Brawijaya University, Indonesia \\ *Corresponding author.Email: moh.amrullah826@gmail.com
}

\begin{abstract}
The excellent progress of Bali's tourism has a good impact on the economic development of Bali Province, but the imbalance in tourism development between North Bali and South Bali produces several negative impacts, one of those impacts is Income Inequality. This study is intending to explore the relationship between the sum of Hotels, Tourist, Motor Vehicle Tax, Motor Vehicle Fuel Tax, and Literacy toward Income Inequality in Bali Province. This study uses Panel Data Multiple Regression using Fixed Effect Model utilizing 9 districts in Bali Province as cross-section data with year intervals from 2012 to 2018. This study found that all independent variables have a significant effect on Income Inequality in Bali Province. The Hotels, The Motor Vehicle Tax, and The Motor Vehicle Fuel Tax variables have no significant effect to Income Inequality. Meanwhile, Tourist and Literacy significantly affect income inequality with a negative relation. Literacy and Tourist arrivals can mitigate Income Inequality and the development of poverty follows the trends of development of Income Inequality in Bali Province.
\end{abstract}

Keywords: Inequality, Tourism, Tax, Education, Bali Province.

\section{INTRODUCTION}

The first income inequality study by reviewing the leverage of economic growth on income inequality is founded in 1955 by Kuznets. His studies exhibit that income inequality will be unequal in the initial phase of growth. In the long run, income inequality will decrease and economic growth is still increasing.

Following Jarjarzadeh \& Eqbali [1], Governments can create differences between income classes by receiving all kinds of expenditures or can influence the distribution of income through transfer payments or taxes; The argument for the role of taxes in income redistribution arises because of that issue.

Currently, tax issues are the focus of policy and research programs [2]. Admittedly, developed and developing countries have dramatically lowered the rate of tax, then income inequality has risen sharply over the past decade, resulting in outrage around the world. Some of the most eminent economists have again suggested taxation as a capable solution to promote more equitable income distribution [3].
Taxation is one of the few ways to affluent may be made less prosperous. Taxes had only sufficient hit in mitigating Income inequality in developed countries and less successful in reducing income inequality problems occurring in developing countries. The ultimate tax tool to achieve progressivity are various wealth taxes and the individual income tax. Neither wealth taxes nor the individual income tax these taxes is not particularly effective in developing countries in mitigating Income Inequality problems [4].

The issue of income distribution does not only concern taxation, but also influences the minds of policy makers in this presume. A proper understanding of the distributive impact of ordinary taxes and their different measurements can help towards a fairness-oriented tax network, without compromising efficiency [1].

Generally, empirical facts in both developing and developed countries show that the round effect of taxes on the distribution of income is largely limited and the fundamental changes in tax arrangements have a slight effect of distribution. On the other hand, the distributive impact of public spending, especially targeted social costs, can positively impact equity and 
reduce poverty [1]. However, taxes on income distribution with distributive impact are relevant, particularly in tax justice and tax cases.

The reached illation found that the redistributive effects of taxes are weak, mainly for developing countries [5]. However, some of these researches discover a significant effect for large changes in the tax structure. Meanwhile, another variable that effect on Income Inequality is Tourism. Tourism is one of the triggering engines that can drive a country's economy. Through its various uniqueness and attractiveness, tourism seems to be an attraction that encourages domestic and international tourists to visit tourist sites directly. In its development, many countries compete to develop the tourism sector in an effort to increase tourist visits to their countries.

The Government of Indonesia targets as many as 20 million foreign tourists to visit Indonesia to develop the tourism sector. The foreign exchange earnings target of 17.6 billion US dollars. Tourism sector income will increase when tourist visits are high [6]. According to the Central Statistics, cumulatively from January to December 2018, Indonesia recorded 15.8 million foreign tourist arrivals. The sum of visits grew by $23.44 \%$ compared to the previous year, which amounted to 12.8 million foreign tourists.

The study related to the relationship of Tourism to Income Disparity is discussed [7], which compares tourism to distribution of income in ASEAN. The study findings are found about negative results on Income Inequality of income distribution in ASEAN. Meanwhile, different results found in [8] related to economic growth towards distribution of income of Bali Province period 2006 to 2015 found the tourism sector represented by trade, hotel and restaurant data that were positive for the income distribution.

The next variable that effect on Income Disparity is education. Education plays an important role in determining the distribution of income and the level of wages of workers [9]. That study discovers a significant relation between Income Inequality and education with a positive relation in Indonesia. It is due to over-education, which causes very large differences in skills between higher education and lower education, resulting in inequality.

Research related to the relationship between literacy rates and income distribution Income Inequality discussed in [10] discusses the analysis of factors affecting income distribution Income Inequality in West Sumatra from 2010 to 2016. The results of the study found that GDP per capita and open unemployment rates have a positive influence and significant to the unequal distribution of income. While the Literacy Rate has a significant effect and a negative relation to Income Disparity. Further, Literacy rates and labor participation had positive and significant effects on the unequal distribution of income in Indonesia [11].

This paper will determine the relationship between tourism, taxes, and, education on Income Inequality in Bali Province using time series data on 2012 until 2018 in 9 districts/city in Bali Province. Through this research, testing will be performed to find out the relationship between tourism, taxes, and, education on inequality.

\section{RESEARCH METHOD}

The research method of this paper employs quantitative research using Multiple Regression. The Software of E-views Series 10 is used in this study as an analysis tool assisting data tabulation. This study uses secondary data sourced from TPID Regional Revenue Agency and Bali Province Central Statistics Bureau. This paper employs data from 9 districts/cities in Bali Province with time-series data from 2012 to 2018 . The independent variables are the sum of hotels, tourist, motor vehicle tax, motor vehicle fuel tax, and literacy rate. Meanwhile, the Dependent Variable in this study is the Income Inequality using Gini Ratio as a proxy. The research model in this study is formulated as follows:

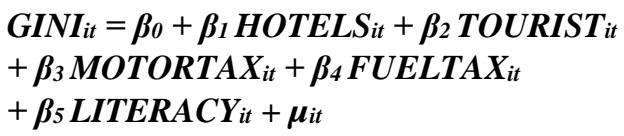

Based on the Equation (1), GINI is the Income Inequality Variable; HOTELS is the sum of hotels; TOURIST is the sum of visiting tourist, MOTORTAX is a motor vehicle tax; FUELTAX is a motor vehicle fuel tax; and LITERACY is the literacy rate. Period $t$ is Time Series data, while $\mu$ is residual / error value.

GINI Variable which is Gini Index is a gauge of Income Disparity with the range from 0 (impeccable equalization) to 1 (the highest range of income disparity) This variable uses data in Gini index percentage.

HOTELS Variable is the sum of hotels in the province of Bali in the period 2012 to 2018 in 9 districts/city in Bali Province. The hotel variable involves the total number of star and non-star hotels in Bali. 
TOURIST Variable is the sum of tourists visiting both local and foreign tourists from 2012 to 2018 in 9 districts/city in Bali Province. LITERACY Variable is the literacy rate that occurred in Bali Province from 2012 to 2018 in 9 districts/city in Bali Province.

MOTORTAX Variable is the tax of Motor through Jarque-Bera Test to examine Normality Test, Durbin-Watson Stat to verify Autocorrelation Test, Multicollinearity Test with Variance Inflation Factors, and Heteroscedasticity assumption using Breusch-Pagan-Godfrey. The result of Jarque-Bera Test discovers P-Value of The Jarque-Bera Test is

Table 1. The Result of Diagnostic Test

\begin{tabular}{|c|c|c|}
\hline Variable & Coefficient & Prob. \\
\hline Normality Test using Jarque Bera & 0.771679 & No Autocorrelation \\
\hline Autocorrelation Test using Durbin Watson Stat & 2.082419 & No Multicollinearity \\
\hline Variance Inflation Factors for Multicollinearity Test & 5.709 & Homoscedasticity \\
\hline Breusch Pagan Godfrey for Heteroscedasticity Test & 0.2906 & \\
\hline
\end{tabular}

Source: E-Views Data Processing Results

Vehicle. This tax is levied on the ownership of motor vehicles. This variable uses data in units of rupiah, Indonesia currency. FUELTAX Variable which is The Motor Vehicle Fuel Tax, is levied a tax on motor vehicle fuel that is provided or considered used for motor vehicles, including fuel used for vehicles traveling on water. Fuel for Motorized Vehicles is all types of liquid or gas fuels used for motorized vehicles. This variable uses data in units of rupiah, Indonesia currency.

In an effort to avoid bias so the estimation model has the characteristics of BLUE (Best, Linier, Unbiassed Estimator), this study is estimating a Classic Assumption Test for Panel Data Regression including Heteroscedasticity, Multicollinearity, Normality, and Autocorrelation Tests [12]. After, the Classical Assumption Test is performed, the Testing Effect will be done. Testing Effect includes a test of significance and the relationship between the independent variable and the dependent variable, through testing the influence of variables through the Coefficient of Determination, Simultaneous Test, and Partial Test.

\section{RESULT AND DISCUSSION}

\subsection{Result}

Table (1) contains the result of the Diagnostic Test. Classical assumption test has been tested
0.771679 . It means that the residual data is normally distributed and there is no abnormal data because that $\mathrm{P}-\mathrm{V}$ alue is bigger than 0.05 .

The next classical assumptions test is DurbinWatson to verify Autocorrelation Test. The result shows Durbin Watson Stat is 2.281419 with $\mathrm{dL}$ in 1.3592 and dU 1.7689. It means Durbin-Watson Stat is greater than $\mathrm{dU}$ and the value of $(4-\mathrm{dw})$ is greater than dU, so there is no Autocorrelation. The result of Multicollinearity Test with Variance Inflation Factors (VIF) shows that Variance Inflation Factors value is 5.709. It shows The VIF is lower than 10 and Multicollinearity does not occur. The result of Heteroscedasticity assumptions shows that BreuschPagan-Godfrey's P-Value is 0.2906. It means that PValue is bigger than 0.05 , so heteroscedasticity does not occur.

The statistical outcome displayed in Table (2) shows that all variables, including hotels, tourist, motortax, fueltax, and literacy, are significant to Gini Index with a significant level at 10 percent. The significance value, P-Value of Hotels is 0.1650 . It means that Hotel's P-value is bigger than 0.1, so partially Hotels Variable is not significant to Gini Index. Next, P-Value of Tourist is 0.0887 . It means that Tourist is significant to Gini. 
Table 2. The Estimation Result of Fixed Effect Regression Model

Dependent Variable: GINI

\begin{tabular}{|l|c|c|}
\hline Variable & Coefficient & Prob. \\
\hline C & 0.687850 & 0.0168 \\
\hline Hotels & $-1.27 \mathrm{E}-06$ & 0.1650 \\
\hline Tourist & $-5.43 \mathrm{E}-08$ & 0.0887 \\
\hline Motortax & $5.15 \mathrm{E}-13$ & 0.1120 \\
\hline Fueltax & $-5.03 \mathrm{E}-13$ & 0.1356 \\
\hline Literacy & -0.015394 & 0.0486 \\
\hline R-squared & \multicolumn{2}{|c|}{0.908208} \\
\hline Prob (F-statistic) & 0.071796 \\
\hline
\end{tabular}

Source: E-Views Data Processing Results

The significance value, P-Value of Motortax Variable is 0.1120 . That value is greater than 0.1 , so partially Motortax Variable is not significant to Gini Index. Then, P-Value of Fueltax Variable is 0.1356. That value is greater than 0.1 , so partially Fueltax Variable is also not significant to Gini Index. P-Value of Literacy Variable is 0.0486 . It means that value is lower than 0.1 and partially Literacy is significant to Gini.

Based on those results, the variables with a significant effect on Income Inequality are Tourist and Literacy. Tourist's coefficient is -0.0000000543 which has negatively effect on Inequality. That coefficient means the one point of increase in Tourist will decrease 0.0000000543 of Income Inequality in Bali Province. Further, the coefficient of Literacy is 0.015394 which negatively affects Inequality. That coefficient means the one point of increase in Literacy will decrease 0.015394 of Inequality.

The $\mathrm{R}^{2}$ value shows 0.908208 that all independent variables explain $90.82 \%$ of Gini and other variables outside the research model can explain $9.18 \%$.
Meanwhile, the $\mathrm{F}$ value probability is 0.071796 . It means that the model is declared significant using a significance level of $10 \%$ and the independent variables in the research model synchronously own a significant effect on Gini as dependent variable.

\subsection{Discussion}

The independent variables including hotels, motortax, and fueltax possess no significant relation to Gini. That result is similar to [13], which found that all the tax variables are not statistically significant.

This study can be announced that Motortax and Fueltax in the period 2012 - 2018 in 9 districts/city in Bali Province are unable to reduce Income Inequality in Bali Province. This result is similar and supports the previous research that found the major tax equipment for achieving progressivity are various wealth taxes and the individual income tax. Neither wealth taxes nor the individual income tax these taxes is not particularly effective in developing countries in mitigating Income Disparity problems [4].

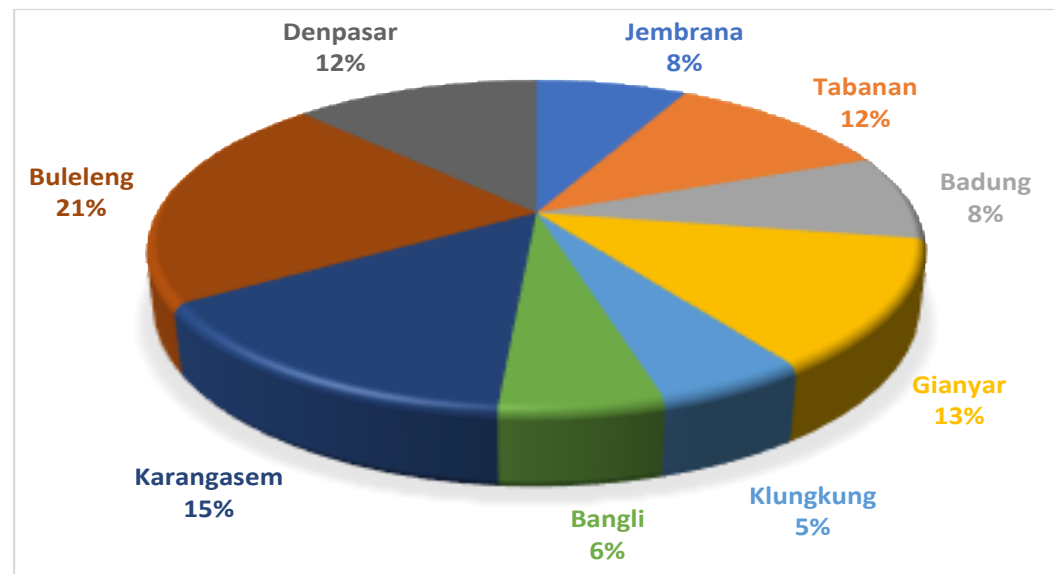

Figure 1 Regional Poverty in Bali Province in 2020

Source: Bali Province Central Bureau of Statistics 
Based on that research, no tax instrument will affect inequality because Indonesia is a developing country. This result is very different from Leu's research, which analyzes the nexus government policies on income distribution and poverty in Switzerland. The study found the effect of all taxes is mitigating Gini Index [14].

Based on Figure (1), discussing Income Inequality and poverty, Bali Province is one of the provinces with the lowest poverty rates in Indonesia, but Bali Province is known to have high-Income Inequality in the distribution of poverty rates between districts. Bali Province has of 165,190 poor people population. The lowest number of poor people in Bali Province occurs in Klungkung Regency, amounting to 8,760 people.

The regency with the highest sum of poor people is Buleleng Regency, with 35,250 poor people. Further, Buleleng Regency donates $21 \%$ and Klungkung Regency only $5 \%$ to the sum of poor people in Bali. It indicates that the distribution of the poor people in Bali is following income inequality. In other words, The development of poverty follows the trends of income inequality development in Bali Province.

In an effort to create a tax role that influences Income Inequality and can even reduce Income Inequality, it is necessary to adjust policies according to Troiano's research exploited the introduction of three major policy reforms and found that all tax policy reforms under consideration increase economic inequality, rather than reduce it, as policymakers intended [15]. So, government must implement policies that are targeted to create conditions that lead to a reduction of Income Inequality through the efficiency of tax policies.

It may be due to corruption, understating of companies income to evade tax, tax evasion on the part of the rich and lack of inclusive growth performance of the Nigerian economy. Further, this result supports the late result which found the weak effect of tax redistribution, especially for developing countries [16]. The use of Motortax and Fueltax variable are the novelty in this study because previous researchers rarely use these variables.

Further, the result that explains hotels with no significant relation to Gini is similar to a previous study from Nuryanto's research who found that Bali tourism has not been able to mitigate Income Inequality [8]. This result weakens the theory from Yoeti [17] things that need to be considered in the development of tourism are tourists, transportation, tourism objects, service facilities. Service Facilities like hotels needed in the development of tourism, but that has not been able to reduce Income Inequality in Bali.

Meanwhile, this research discovered that the independent variables, tourist and literacy, have a significant effect on the dependent variable. That result is similar to the study from Fahlevi and Syanur [7] that found tourism income had a positive relation and significant to income inequality. This study discovered tourism and income inequality have a negative impact, so this is the novelty of research that found different relation with the same variable.

Further, the result of literacy variable has significant effect on the dependent variable, is similar to Arifka's research that found Literacy Rate owns negative relation and significant on income inequality [10]. All independent variables have a significant effect on the dependent variable. To improve Income Inequality incomes in the Province of Bali, it would be effective if the government gives more attention to increasing tourist visits and improving the education of Bali Province.

Local governments should pay more attention to the four regions with the highest poverty rates to alleviate poverty and income inequality, namely Buleleng, Karangasem, Gianyar, and Tabanan Regencies. All of these areas are known to be located in the northern part of Bali, so that the development of the tourism sector should exploit North Bali.

\section{CONCLUSION}

In the estimates model, the result shows all independent variables have simultaneously significant effect to Inequality. The Hotels, Motortax, and Fueltax variables have no significant effect on the dependent variable. Meanwhile, Tourist and Literacy have a significant effect on Income Inequality and negatively relates to Income Inequality in Bali Province. Education and tourist arrivals can mitigate Income Disparity and the development of poverty is following the trends of development of Income Inequality in Bali Province. In an effort to alleviate poverty and the trend of income inequality, local governments should pay more attention to the northern part of Bali and the development of the tourism sector should exploit North Bali. 
Testing can be done using other independent variables that are possible to affect Income Inequality in the province of Bali. The Hotels, Motortax and Fueltax variable are the novelty in this study because these variables are rarely used by previous researchers. Further, this study discovers a negative connection between income inequality and tourism.

\section{AUTHORS' CONTRIBUTIONS}

The authors' contribution is related to family firms, local governments, and Covid-19 Pandemic. This article provides insight to local governments in alleviating regional income inequality related to poverty during the Covid-19 pandemic.

\section{ACKNOWLEDGMENTS}

The authors express their gratitude to the partners who contributed to the preparation of this article, both data collection and article publication.

\section{REFERENCES}

[1] N. Nantob, Taxation and income inequality in developing countries: An empirical investigation, Econ. Bull., vol. 36, no. 3, pp. 1508-1522, 2016.

[2] D. Duncan and K. S. Peter, Tax progressivity and income inequality, Choice Rev. Online, vol. 32, no. 7, pp. 32-4008-32-4008, 2008, doi: 10.5860/choice.32-4008.

[3] E. Militaru and L. Stanila, Income Variability in Romania: Decomposing Income Inequality by Household Characteristics, Procedia Econ. Financ., vol. 26, no. 15, pp. 227-233, 2015, doi: $10.1016 / \mathrm{s} 2212-5671(15) 00823-0$.

[4] J. M. Vazquez, B. M. Dadson, and V. Vulovic, International Center for Center for Public Policy, Work. Pap., vol. 12, pp. 1-48, September, 2012.

[5] B. Martorano, Taxation and Inequality in Developing Countries: Lessons from the Recent Experience of Latin America, J. Int. Dev., vol. 30, no. 2, pp. 256-273, 2018, doi: 10.1002/jid.3350.

[6] F. N. Rahma and H. R. Handayani, Pengaruh Jumlah Kunjungan Wisatawan, Jumlah Objek Wisata dan Pendapatan Per Kapita terhadap Penerimaan Sektor Pariwisata di Kabupaten
Kudus, vol. 2, no. 2, pp. 1-9, 2013, doi: Http://Ejournal-S1.Undip.Ac.Id/Index.Php/Jme.

[7] F. Fahlevi and S. Syahnur, Pengaruh Pariwisata Terhadap Ketimpangan Distribusi Pendapatan di Associaton od Southeast Asian Nations, vol. 3, no. 4, pp. 452-463, 2018.

[8] D. T. R. J. Nuryanto, Pariwisata, Pertumbuhan Ekonomi dan Ketimpangan Distribusi Pendapatan di Bali (Hipotesis Kurva Kuznets), Indonesia Treas. Rev. J. Perbendaharaan, Keuang. Negara dan Kebijak. Publik, vol. 2, no. 3, pp. 43-54, 2018, doi: 10.33105/itrev.v2i3.61.

[9] A. Nadya and Syafri, Ketimpangan Distribusi Pendapatan, Media Ekon., vol. 27, no. 1, pp. 3752, 2019.

[10] F. Arifka, Analisis Faktor-Faktor yang Mempengaruhi Ketimpangan Distribusi Pendapatan di Sumatera Barat, Menara Ekon., vol. 2, no. 4, pp. 41-52, 2018.

[11] R. M. Arsyillah, Analisis Peran Pendidikan dan Ketenagakerjaan terhadap Ketimpangan Pendapatan di Indonesia (Studi Kasus 34 Provinsi di Indonesia tahun 2013-2017), Skripsi, 2019.

[12] S. T. Wahyudi, Konsep dan Penerapan Ekonometrika Menggunakan E-Views, Edisi Kedu. Depok: Rajagrafindo Persada, 2020.

[13] C. Ugondah and N. Nyewe, Taxation and Income Inequality in Nigeria, Adv. J. Econ. Mark. Res., vol. 4, no. 3, 2019.

[14] R. E. Leu, R. L. Frey, and B. Buhmann, Taxes, Exp. and Income Distribution in Switzerland, J. Soc. Policy, vol. 14, no. 3, pp. 341-360, 2009, doi: $10.1017 / \mathrm{s} 0047279400014781$.

[15] U. Troiano, Do Taxes Increase Economic Inequality? A Comp. Study Based on the State Personal Income Tax, SSRN Electron. J., no. 107, pp. 3-4, 2018, doi: 10.2139/ssrn.3092770.

[16] E. M. Zolt and R. M. Bird, Redistribution Via Taxation: The Limited Role of The Personal Income Tax in Developing Countries, UCLA Law Rev., vol. 52, no. 6, pp. 1627-1695, 2005.

[17] Yuliani, Strategi Komunikasi Dinas Kebudayaan Pariwisata dan KOMINFO (DISBUDPAR) dalam Meningkatkan Kunjungan Wisatawan di Desa Pampang Kota Samarinda, eJournal Ilmu Komun., vol. 1, no. 3, pp. 450-464, 2013. 